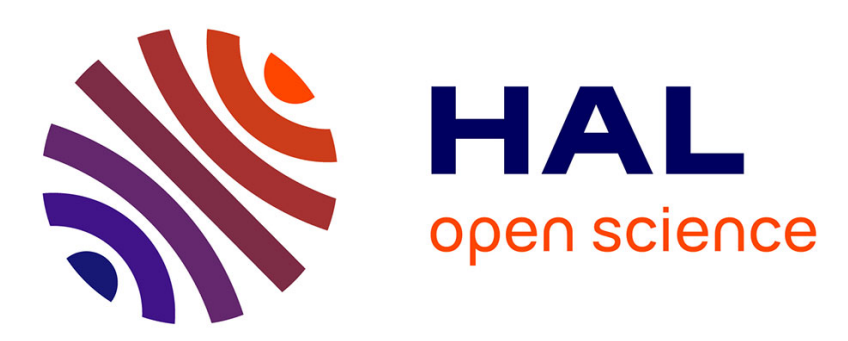

\title{
Crustal structure beneath the Iberian Peninsula and surrounding waters: a new compilation of deep seismic sounding results
}

J. Diaz, J. Gallart

\section{- To cite this version:}

J. Diaz, J. Gallart. Crustal structure beneath the Iberian Peninsula and surrounding waters: a new compilation of deep seismic sounding results. Physics of the Earth and Planetary Interiors, 2009, 173 (1-2), pp.181. 10.1016/j.pepi.2008.11.008 . hal-00532185

\section{HAL Id: hal-00532185 \\ https://hal.science/hal-00532185}

Submitted on 4 Nov 2010

HAL is a multi-disciplinary open access archive for the deposit and dissemination of scientific research documents, whether they are published or not. The documents may come from teaching and research institutions in France or abroad, or from public or private research centers.
L'archive ouverte pluridisciplinaire HAL, est destinée au dépôt et à la diffusion de documents scientifiques de niveau recherche, publiés ou non, émanant des établissements d'enseignement et de recherche français ou étrangers, des laboratoires publics ou privés. 


\section{Accepted Manuscript}

Title: Crustal structure beneath the Iberian Peninsula and surrounding waters: a new compilation of deep seismic sounding results

Authors: J. Díaz, J. Gallart

PII:

S0031-9201(08)00353-1

DOI: doi:10.1016/j.pepi.2008.11.008

Reference: PEPI 5111

To appear in: Physics of the Earth and Planetary Interiors

Received date: 7-3-2008

Revised date: 16-10-2008

Accepted date: 12-11-2008

Please cite this article as: Díaz, J., Gallart, J., Crustal structure beneath the Iberian Peninsula and surrounding waters: a new compilation of deep seismic sounding results., Physics of the Earth and Planetary Interiors (2008), doi:10.1016/j.pepi.2008.11.008

This is a PDF file of an unedited manuscript that has been accepted for publication. As a service to our customers we are providing this early version of the manuscript. The manuscript will undergo copyediting, typesetting, and review of the resulting proof before it is published in its final form. Please note that during the production process errors may be discovered which could affect the content, and all legal disclaimers that apply to the journal pertain. 
$-1-$

\section{Crustal structure beneath the Iberian Peninsula and surrounding}

2 waters: a new compilation of deep seismic sounding results.

4 J. Díaz* and J. Gallart

5 Institut of Earth Sciences "J. Almera", CSIC. c/ Sole Sabaris s/n, 08028 Barcelona, 6 Spain.

7 * Corresponding author. Tel: +34 9340954 10, Fax: +34 934110012 E-mail:

$8 \quad$ jdiaz@ija.csic.es

\section{Abstract}

13 We present here an updated compilation of crustal parameters beneath the Iberian

14 Peninsula and surrounding waters, inferred from extensive deep seismic exploration

15 performed in the last three decades. Firstly, the more relevant experiments developed in

16 both terrestrial and marine domains are revisited, together with the corresponding

17 seismic velocity-depth models published that reveal the characteristics of the different

18 tectonic domains sampled, including oceanic zones, continental margins, orogenic and

19 rift belts. The results are summarized in three crustal transects sketched along

20 representative directions. Secondly, we compiled the Moho depths along all the

21 available seismic profiles to produce a geo-referred database. This database has then

22 been interpolated using kriging algorithms to obtain a continuous Moho depth model, in

23 the form of a regular grid file. This integrative Moho map for a key area in the Western

24 Mediterranean documenting the interaction between European and African plates can 


\section{-2 -}

25

26

27

28 Keywords

29

30

31

32

33

34 Since the early 70 s, the crustal structure beneath the Iberian Peninsula and its

contribute to constrain further regional studies, either at crustal, lithospheric or mantle scales.

Iberia, Crustal model, Moho depth

\section{Introduction}

continental margins has been explored by a high amount of controlled-source seismic experiments, which provided information about the seismic wave velocities and the geometry and depth of the main crustal interfaces. The purpose of this contribution is to revisit those results, with a special emphasis in compiling the crustal depths, to provide a regional Moho-depth model of the whole area. Even if information about physical properties of the crust can be achieved after a number of geophysical techniques (tomography, receiver functions, potential fields analysis, etc.), the wide-angle reflection/refraction seismic profiles appear to be the most reliable technique to constrain the velocity-depth distribution and Moho depth, as the position of the main interfaces and the seismic velocity values are readily inferred from the data through modelling with determinable uncertainties. First compilations of seismic crustal parameters in the Iberian Peninsula were attempted by Banda et al. (1983) and Banda (1988), but since then a lot of subsequent experiments have been carried out, mainly in the northern part of the Peninsula, the Valencia Trough, the Betics, the Gulf of Cadiz and the Iberian Massif. Compilations available at global or continental-european scales 
50 (Meissner, 1986, Dezès and Ziegler, 2001, Laske et al. 2001) do not resolve significant

51 regional features of this key area of the Western Mediterranean, which deserves

52 particular attention in present-day integrated research initiatives in European

53 geosciences. These researches would certainly benefit from the existence of large,

54 upgraded geo-referred databases, and the continuous Moho depth model we infer here

55 can contribute to constrain the lithospheric features on the interaction domains between

56 European and African plates.

57

58 The main tectonic domains in the Iberian Peninsula and its surrounding waters that will

59 be considered in revisiting the seismic datasets are: a) The Iberian Massif, extending at

60 the central and western part of Iberia, where the Hercynian basement outcrops or is

61 covered by almost undeformed Tertiary sediments; b) the areas strongly affected by the

62 Alpine orogenesis: i) the Pyrenees, extending from the Mediterranean sea to the

63 Cantabrian Mountains, ii) the Iberian Chain, an area of Mesozoic cover deformed

64 during the Alpine compression, iii) The Betics Chain, related to the complex tectonics

65 of the Gibraltar Arc System; c) the Valencia Trough, a basin developed during the

66 Neogene as part of the general Cenozoic rift system of western Europe, d) the Atlantic

67 Margins, that can be subdivided into three broad zones: the Gulf of Cadiz, an active area

68 with strong sedimentary cover and significant seismicity, the Western Atlantic, a

69 classical example of passive margin, and the Cantabrian Margin, characterised by a very

70 abrupt topography.

73 Outline of Iberian seismic exploration experiments 
75 In order to compile the crustal parameters, we have first revisited more than 50 research

76 projects developed during the last 30 years in terrestrial and marine domains around

77 Iberia. We selected those experiments focused in the whole crustal structure, carried out

78 in most cases by academic institutions, and did not consider the high resolution profiles

79 performed by oil prospecting companies, mainly focused in the sedimentary features.

80 Figure 1 summarizes the location of the compiled refraction/wide-angle reflection and

81 the multichannel reflection profiles. An enormous amount of publications have resulted

82 from these experiments, and only significant, key references are listed here on the

83 bibliography, but which may allow the interested reader to found most of the published

84 works. A more exhaustive compilation of publications is presented in Gallart et al. 85 (2006).

86

87 The pioneer seismic experiments around Iberia were marine refraction investigations, 88 using a small number of OBS or sonobuoys, carried out in the Valencia Trough89 Balearic domains (Fahlquist, 1963, Hinz, 1973) and in the Atlantic Margin (Purdy, 90 1975). The first seismic experiments on land where performed during the early 70 's in 91 the Algarve region (S Portugal) by an international team leaded by the Zurich 92 University (Mueller et al., 1973, Sousa Moreira et al., 1978), extending soon afterwards 93 to Southern Spain (Udías 1975). In particular, a $500 \mathrm{~km}$ long terrestrial profile through 94 the Betics (Banda and Ansorge, 1980) and 3 lines crossing the Alboran Sea where 95 recorded using a limited number of analogical stations, shifted between repeated shots 96 at a same point to densify the profile (Working Group for Deep Seismic Sounding in 97 Alboran 1974, 1978). During the late 70's, new profiles where acquired in Southern 98 Spain, sampling the Gulf of Cadiz, the Gibraltar area, the Iberian System and the 99 Balearic Islands (Udías, 1980, Medialdea et al., 1986, Barranco et al., 1990, Zeyen et 
100 al., 1985, Banda et al., 1980). The central part of the Iberian Massif was also sampled in

101 the late 70's, using quarry blasts as energy sources (Banda et al., 1981).

102

103 The Pyrenees were exhaustively explored by deep seismic profiles during the late 70's.

104 Two E-W profiles throughout the northern and southern domains of the chain were

105 recorded (Daignières et al., 1981, Gallart et al., 1981), as well as a N-S transect and

106 multiple complementary profiles in the eastern Pyrenees (Gallart et al., 1980). Up to 64

107 analogical instruments and near to 20 explosions were used, reaching station spacing

108 between 3 and 5 km. In 1984, the French "Étude Croûte continentale et Oceéanique par

109 Réflexion et réfraction Sismique" (ECORS) programme acquired a $300 \mathrm{~km}$ long, N-S

110 oriented multichannel marine profile in the Bay of Biscay (Marillier et al., 1988, Bois

111 and Gariel, 1997). In the following years, the ECORS-Pyrenees Team carried out the

112 first academic deep multichannel seismic profile on land implemented partially in

113 Iberia, that crossed the Pyrenees in a NNE-SSW direction and provided high-quality

114 data to constrain the Pyrenean orogenesis (ECORS Pyrenees Team, 1988, Choukroune

115 1989). Complementary wide-angle profiles were also acquired along the same line

116 (Surinach et al., 1993, Daignières et al., 1998). Still in the ECORS framework, another

117 transect was recorded later on in the Western Pyrenees (ECORS-Arzacq, Daignières et

118 al., 1994, Damotte, 1998).

120 In the early 80 s the seismic exploration activity on land was focused in the Iberian

121 Massif. The NW corner of Iberia was studied in a widespread survey, involving inter-

122 station distances of 1 to $2.5 \mathrm{~km}$. (Córdoba et al., 1987, 1988). Those profiles provide

123 one of the few examples of direct modelization of S wave velocities (Téllez et al., 1993,

124 Téllez and Córdoba, 1998). Some complementary profiles where fired in N Portugal 


\section{$-6-$}

125 (Mendes-Victor et al., 1988) and additional ones where recorded in central Spain

126 (Suriñach and Vegas, 1988). During the same time period, the DSDP consortium

127 decided to establish drill holes near the limit between the Galicia Bank and the Atlantic

128 abyssal plain, and a preliminary multichannel seismic survey was performed over this

129 zone, acquiring a number of deep penetration profiles mainly oriented E-W (Groupe

130 Galice, 1979, Mauffret and Montardert, 1988). The profiling activity in the Atlantic

131 Margin continued in 1986-87 by a British wide-angle-/refraction survey in the Tagus

132 Abyssal Plain (Whitmarsh et al., 1990, Pinheiro et al., 1992) and by the Reframarge

133 experiment, using the same technique to explore the limit between the Galicia Bank and

134 the Iberian abyssal plain (Whitmarsh et al., 1996). Later on, in 1990, the Lusigal

135 experiment sampled again the Tagus Plain using in this case multichannel seismic

136 profiles (Beslier et al., 1993).

138 In 1988 the Valencia Trough was largely explored within the VALSIS experiment. Up

139 to $200 \mathrm{~km}$ of multichannel seismics were acquired, including common deep point,

140 common offset point and expanding spread profiles (Watts et al., 1990, Torné et al.,

141 1992, Pascal et al., 1992). The shots from some of these profiles where recorded

142 onshore by portable seismic stations, providing the first 'onshore-offshore' transects in

143 Iberia (Gallart et al., 1990). The same geographical area, between the Balearic islands

144 and NE Iberia, was explored in 1989 in a wide-angle experiment, using explosive

145 sources recorded by 110 land stations and 10 OBS (Dañobeitia et al., 1992) to constrain

146 the velocity-depth structure.

147

148 In the late 80s, the large scale "Iberian Lithospheric Heterogeneity and Anisotropy"

149 (ILIHA) experiment provided relevant information about the crustal and upper mantle 
150 structure beneath Iberia, including evidences of the presence of seismic anisotropy in

151 the uppermost mantle. Up to $6800 \mathrm{~km}$ of profiles crossing the Peninsula along different

152 azimuths where recorded with station spacing of about $4 \mathrm{~km}$ (Díaz et al., 1993a, 1993b).

153 In the same period, a number of new profiles crossing the Eastern Betics where acquired

154 with higher station density (Banda et al., 1993).

155

156 In the early nineties, the focus of activity shifted to multichannel reflection profiles, in

157 the framework of the Spanish "Estructura Sísmica de la Corteza Ibérica" (ESCI)

158 Program that allowed to record up to $450 \mathrm{~km}$ of terrestrial and $1325 \mathrm{~km}$ of offshore

159 seismic profiles in southern, eastern and northern Iberia. On land, an NW-SE oriented

160 profile was acquired in the Betics (Garcia-Dueñas et al., 1994), a short profile

161 connecting the ECORS line to the Mediterranean coast was implemented across the

162 Catalan Coastal Range (Gallart et al., 1994a), and two N-S and E-W profiles were shot

163 in the in Cantabrian Mountains (Pérez-Estaún, 1994, Pulgar et al. 1996, Gallastegui et

164 al., 1997). Offshore, two seismic profiles were acquired in southern Spain, one sampling

165 the northern part of the Alboran Sea in a NNE-SSW direction and the second one,

166 oriented approximately E-W, connecting to the SudBalearic basin (Booth-Rea et al.,

167 2007). The first profile was also recorded on land by a few seismic stations (Gallart et

168 al., 1995). The Alboran Sea was explored again in 1992 by a set of short $(50 \mathrm{~km})$

169 refraction profiles in its NW part recorded on land by up to 24 stations (Gallart et al.,

170 1994b) and by the larger scale CONRAD experiment that recorded five multichannel

171 seismic profiles oriented approximately N-S crossing the whole basin (Watts et al., 172 1993). 
$-8-$

174 The marine component of the ESCI Programme included also the acquisition of another

175 multichannel profile in the Valencia Trough, oriented NW-SE, between Tarragona coast

176 and S of Mallorca island, recorded also onshore (Gallart et al., 1995), and allowing in

177 this way to complete a $700 \mathrm{~km}$-long seismic transect from the Pyrenees to the South

178 Balearic Basin (Vidal et al., 1998). The ESCI Programme was completed in 1993 with

179 the acquisition of two profiles in the North-Iberian Margin, one oriented E-W sampling

180 the Hercynian structures and the other oriented N-S, extending northwards the

181 previously acquired land profile to obtain a transect orthogonal to the main structures

182 (Alvarez-Marrón et al., 1996, Ayarza et al., 1998). In both cases the profiles were

183 recorded by land stations to obtain wide-angle data that control the velocity structure

184 (Fernández-Viejo et al., 1998; Gallastegui et al., 2002). Extensive exploration on land of

185 the northern part of Iberia was also performed in the 90s within two research projects

186 that recorded a large E-W refraction/wide-angle reflection profile covering a total of

$187960 \mathrm{~km}$ from Galicia to the Pyrenees Chain, as well as a set of transverse profiles

188 sampling the transition between the Duero Basin and the Cantabrian Mountains (Pulgar

189 et al. 1996; Fernández-Viejo et al., 2000, Pedreira et al., 2003).

190

191 In the mid-nineties, the French project LISA sampled different areas of the western

192 Mediterranean from seismic multichannel profiling (Mauffret et al., 2001, Nercessian et

193 al., 2001). Five of the acquired profiles were shot in the vicinity of the eastern

194 termination of the Pyrenees and were recorded by land stations to investigate the

195 transition between the areas affected by the Alpine compression and the Neogene

196 extension (Gallart et al., 2001). However, most of acquisition activity was focused on

197 the marine seismic exploration of the Atlantic margins of Iberia, in the framework of the

198 large scale "Iberian Atlantic Margins" (IAM) European project. Up to $3500 \mathrm{~km}$ of 
-9 -

199 multichannel profiles were acquired in the North-Iberian and Atlantic margins, the

200 Gorringe bank and the Gulf of Cadiz (Banda et al., 1995). Profiles IAM12, oriented N-S

201 along the La Coruña longitude, IAM11 oriented E-W in front the central coast of

202 Portugal and IAM3, oriented NE-SW in front of Cabo San Vicente were recorded on

203 land, providing images of the continent-oceanic transition (Fernández-Viejo et al., 1998,

204 González et al., 1996; González et al., 1999). After the IAM project, additional

205 experiments were implemented in Atlantic Margins, to better constrain the seismic

206 velocity structure. A wide-angle profile, including the deployment of up to 16 OBS, was

207 shot in the same position of the previously acquired IAM9 line (Chian et al., 1999, Dean

208 et al., 2000), exploring the structure of the ocean-continent transition. The northern part

209 of the Atlantic margin was investigated in the ISE97 experiment that acquired more

210 than $4000 \mathrm{~km}$ of multichannel seismics, recorded also by a network of OBS and land

211 stations (Pérez-Gussinye et al., 2003, Henning and Sawyer, 2004). In 1998, the

212 BIGSETS project sampled the epicentral area of the 1755 Lisbon earthquake by up to

$2132700 \mathrm{~km}$ of multichannel seismic profiles.

214

215 The seismic exploration activity in the 21th century started with the investigation of the

216 tectonic evolution of the Gulf of Cadiz, where two main E-W oriented multichannel

217 seismic profiles were acquired in the framework of the TASYO project (Medialdea et

218 al., 2004). The same area was investigated in 2002 by the VOLTAIRE project, which

219 allowed the acquisition of more than $1000 \mathrm{~km}$ of multichannel seismic profiles (Zitellini

220 et al., 2004). The TECALB experiment, carried out in 2004, provided a set of

221 multichannel seismic profiles sampling the Eastern Alboran Sea (Comas et al., 2004). In

222 2006, the West-Med experiment, allowed the acquisition of wide-angle data in the

223 Alboran Sea and the transition to the South Balearic basin, using a network of OBS and 
224 land stations (Galvé et al., 2007). The same area has been investigated in 2006 by the

225 MARSIBAL cruise, using in this case multichannel seismic profiling (Comas et al.,

226 2007).

227

228 After the sinking, in late 2002, of the "Prestige" oil-tanker at about $250 \mathrm{~km} \mathrm{NW}$ of the

229 Galician coasts, an emergency multidisciplinary investigation was launched over the

230 sinking area, located in the limit between the Galicia Bank and the Iberian Abyssal

231 Plain. In this framework, a seismic experiment including multichannel seismic profiles

232 and OBS was carried out on in 2003 (Díaz et al., 2008). At the same year, the

233 MARCONI large scale project investigated the deep structure of the eastern half of the

234 Bay of Biscay. Up to $1800 \mathrm{~km}$ of multichannel seismic profiles were acquired and the

235 signals were recorded by 24 OBS and by a network of 36 land stations to constrain the

236 velocity structure of the area (Ruiz, 2007). Still in 2003, a seismic transect on land was

237 acquired beneath the central part of the Iberian Chain to investigate the presence of a

238 crustal root (Gallart et al., 2004).

239

240 On land, the IBERSEIS experiment, carried out in 2001, provided a high resolution

241 image of the SW Iberian Massif, using both multichannel and wide-angle methods. In

242 the wide-angle profile up to 690 seismic stations where deployed, providing a resolution

243 of 150 to $400 \mathrm{~m}$, that is clearly an order of magnitude higher than all previous

244 experiments (Simancas et al, 2003, Carbonell et al., 2004). In 2007, the ALCUDIA

245 project has allowed to extend $300 \mathrm{~km}$ towards the Northeast the previously acquired

246 IBERSEIS line, providing a complete transect from the Gulf of Cadiz to the Hercynian

247 domain of the Spanish Meseta (Carbonell et al., 2007). 
$-11-$

250 Seismic structure beneath the Iberian Peninsula and surrounding waters

251

252

253

254

255

256

257

258

259

260

261

262

263

264

265

266

267

268

269

270

271

272

273

Iberian Massif

A large part of central and western Iberia is covered by the Iberian Massif, affected by the Variscan orogeny and mostly undeformed since then. The crust is seismically differentiated in three layers and shows a structure similar to other Variscan domains in Europe. The basement has a thickness of $8-12 \mathrm{~km}$ and velocities ranging from 5.9 to 6.1 $\mathrm{km} / \mathrm{s}$ (Banda et al., 1980). Some authors have introduced a low velocity at the bottom of this layer, even if recent high resolution experiments can not confirm such a structure (Palomeras et al., 2008). The intermediate crustal layer, with velocities of $6.2-6.4 \mathrm{~km} / \mathrm{s}$ reaches depths of $23-25 \mathrm{~km}$. A lower crust, with velocities of $6.7-6.8 \mathrm{~km} / \mathrm{s}$ is defined above the Moho discontinuity, located at $30-33 \mathrm{~km}$. A crustal root seems to be present beneath the Central System, where the crustal depth reaches $34 \mathrm{~km}$ as a consequence of a thickening of the middle crust layer (Suriñach and Vegas, 1982). Beneath the Atlantic coast of Iberia, the crust displays thicknesses of $27-29 \mathrm{~km}$ and starts thinning toward the oceanic domain (Díaz et al., 1993a). In SW Portugal, the crust has been modelled with a strong gradient in the upper crust and a pronounced LVZ (Mueller et al., 1973, Sousa Moreira et al., 1978). However, an alternative interpretation assuming a model closer to the one obtained for central Iberia can also explain the data (González et al., 1998). Multichannel seismic profiling across the Variscan belt in SW Iberia revealed the existence of a mid-crustal reflective body, $140 \mathrm{~km}$ long and of variable thickness (up to $5 \mathrm{~km}$ ), that has been interpreted as an Early Carboniferous mantle derived intrusion (Carbonell et al., 2004). Wide-angle modelling along the same profile shows a 31-34 
$274 \mathrm{~km}$ thick crust, with the lower crust thickening to the center of Iberia (Palomeras et al.,

275 2008).

276

277 Alpine Chains

278

279 The presence of a more or less pronounced root underneath the areas that underwent

280 significant deformation during the Alpine orogeny has become apparent since the first

281 seismic investigations in Iberia. In the early 80s the crust beneath the Pyrenean chain

282 was modelled with a sedimentary layer on top of a basement with seismic velocities of

$2836.1-6.2 \mathrm{~km} / \mathrm{s}$ that overlays an undifferentiated mid-lower crust below 11-14 km depth

284 where the velocities reach 6.3-6.4 km/s. The crustal thickness beneath the Pyrenean

285 axial zone reaches $45-50 \mathrm{~km}$, while the northern European crust does not exceed $30 \mathrm{~km}$

286 depth (Daignières et al., 1981, Gallart et al., 1981). This image was confirmed by the

287 ECORS multichannel seismic profile, which shows well-defined reflectors in the entire

288 crust with an overall fan-shape geometry, and a marked crustal thickening from the

289 southern Pyrenean domain towards the Axial zone, depicting an imbrication of the

290 Iberian crust beneath the European one (Choukroune et al., 1990). No evidences for the

291 persistence of a crustal root eastwards, toward the Mediterranean Sea have been inferred

292 either from the land refraction profiles (Gallart et al., 1980) or from the onshore-

293 offshore experiments in the eastern termination of the Pyrenees (Gallart et al., 2001).

294 The important differences in Moho depths between the Iberian and the European

295 domains observed in the central and western Pyrenees are not present in this area, which

296 is marked by a continued thinning seaward, the Moho reaching $25 \mathrm{~km}$ depth in front of

297 Cap de Creus.

298 
299 A remarkable result derived from the extensive seismic exploration in the northern part

300 of Iberia is that all the profiles sampling areas affected by the Alpine orogeny show a

301 crustal structure similar to that inferred for the Pyrenean Chain (Fernández-Viejo et al.,

302 1998; Pedreira et al., 2003). A quasi-continuous crustal root is hence depicted along the

303 strike of the Pyrenean-Cantabrian range where Moho depths reach 46-48 km, with a

304 local, relative thinning to $40 \mathrm{~km}$ depth beneath the Mesozoic sediments of the Basque-

305 Cantabrian Basin. Seismic and gravity modelling in the whole area shows consistent

306 images of a crustal indentation and wedging between the Iberian and the European-

307 Cantabrian Margin crusts (Fernández-Viejo et al., 1998; Gallastegui et al., 2000;

308 Pedreira et al., 2003; 2007). A $10 \mathrm{~km}$-thick lower crustal layer of $6.6-6.8 \mathrm{~km} / \mathrm{s}$ is

309 modelled on top of the Moho. The presence of high velocity bodies embedded at mid-

310 crustal levels has also been inferred from the seismic data, and they have been

311 interpreted as intrusions from the European-Cantabrian Margin lower crust indenting

312 southward the Iberian crust (Pedreira et al., 2003, 2007). A significant thinning of the

313 crust to the westernmost part of the Cantabrian Mountains, where Moho depths are

314 about $30 \mathrm{~km}$, depicts the transition to the zones of the Iberian Massif which had not

315 been significantly reworked by the Alpine orogeny.

316

317 The seismic profiles exploring the other major Alpine domain in Iberia, the Betics

318 Chain, have evidenced the differences between the Iberian Massif and the external and

319 internal Betic domains. In the transition zone to the internal Betics, the crust thins first

320 to $32 \mathrm{~km}$ and then thickens to $37-38 \mathrm{~km}$. The absence of differentiated lower crust

321 beneath the external Betics has been related with the Mesozoic rifting episode of the

322 South-Iberian passive margin (Banda et al., 1993). In an East-West direction, the

323 Palomares-Alhama de Murcia fault system seems to limit two crustal blocks; to the 
324 East, the crust is only of $23 \mathrm{~km}$ thick, and has a high velocity body $(6.9 \mathrm{~km} / \mathrm{s})$ in the

325 lower levels. West of this fault system, the presence of a LVZ $5.4 \mathrm{~km} / \mathrm{s}$ at depths of 7 to

$32612 \mathrm{~km}$ has been inferred from the data. The crustal thicknesses vary strongly, between

327 the $38 \mathrm{~km}$ reached beneath Granada and the $24 \mathrm{~km}$ beneath Adra, close to the Alboran

328 sea (Banda and Ansorge, 1980). SW of Málaga seismic data evidences an anomalous

329 structure that could be explained by a thin crust, a massive presence of peridotites or a

330 combination of both features (Banda et al., 1993). In the Westernmost Betics Chain, the

331 upper, middle and lower crusts are evidenced, with velocities of $6.1,6.4$ and $7.0 \mathrm{~km} / \mathrm{s}$

332 underlying a sedimentary cover that has important thickness variations. The crustal

333 depth varies from $25 \mathrm{~km}$ under the inner arc of the Betics to $31 \mathrm{~km}$ in the coast west of

334 Gibraltar (Medialdea et al., 1986). Towards the Alboran Sea, the velocity-depth

335 distribution is poorly constrained from the published datasets. The crust seems to

336 quickly get thinner, reaching depths of about $15 \mathrm{~km}$ but without showing features of

337 oceanic crust. It overlies an uppermost mantle with apparently low velocities (Hatzfeld

338 and Bensari, 1977; Working Group for DSS in the Alboran Sea 1974, 1978).

340 The results available for the Iberian Chain, an area of Mesozoic cover deformed during

341 the Alpine compression, show an average crustal thickness of 30-32 km for most of the

342 chain, similar to the values in the Central Iberian Massif. However, a local thickening of

343 a few kilometers has been detected in the central northern part of the chain (Zeyen et al.,

344 1985). A similar crustal root has also been observed farther south, along a refraction

345 profile oriented NE-SW where the Moho reaches $40 \mathrm{~km}$ depth (Gallart et al., 2004).

347 Valencia Trough 


\section{$-15-$}

349 The transition between the NE Iberian Peninsula and the Valencia Trough, a basin

350 developed during the Neogene as part of the general Cenozoic rift system of western

351 Europe, is marked by a strong thinning of the crust, changing from $35 \mathrm{~km}$ inland to 15 -

$35218 \mathrm{~km}$ in the center of the basin. The crust thickens again to the SE beneath the Balearic 353 promontory, reaching $30 \mathrm{~km}$ beneath Mallorca island. The basement shows seismic 354 velocities of $6.0-6.1 \mathrm{~km} / \mathrm{s}$, while in the lower crust, where must of the crustal thinning 355 is accommodated, the velocities are of $6.4-6.5 \mathrm{~km} / \mathrm{s}$. The uppermost mantle beneath the 356 axial zone is characterized by a low velocity of about $7.8 \mathrm{~km} / \mathrm{s}$, interpreted as 357 consequence of the rifting process that affected this area. To the SE, in the South

358 Balearic basin, the crust becomes very thin $(6 \mathrm{~km})$ and has probably an oceanic origin 359 (Banda et al., 1980, Dañobeitia et al., 1992, Collier et al., 1994, Vidal et al., 1998).

360

361

362

363

364

366

367

368

369

370

371

372

373

\section{Atlantic and Cantabrian Margins}

In the Atlantic Margins of Iberia the transition from continental to oceanic crust is mapped with significant variations between the different zones. The seismic models obtained beneath the Gulf of Cadiz indicate that the whole area has a continental-type crust, with a progressive thinning from $27 \mathrm{~km}$ in the east to $20 \mathrm{~km}$ in the westernmost area (González et al., 2001). The onshore recordings of an SW-NE oriented MCS profile in front of Cape San Vicente have revealed that the crust undergoes a strong but continuous thinning from $31 \mathrm{~km}$ onshore Iberia to less than $15 \mathrm{~km}$ in the Horseshoe Abyssal Plain, over horizontal distances of 120 km (González et al., 1996).

In front of the coast of central Portugal, the transition between the continental and the oceanic domains has been modelled using wide-angle seismic data (Dean et al., 2000; 


\section{$-16-$}

374 Chian et al., 1999) and imaged with MCS profiling (Pickup et al., 1996). East of

$37510^{\circ} 45^{\prime} \mathrm{W}$, the crust is of continental type, with a smooth uprising of the Moho from 31

$376 \mathrm{~km}$ beneath Iberia to $12 \mathrm{~km}$. West of this longitude, the crust is described as transitional,

377 with an upper layer $2-4 \mathrm{~km}$ thick modelled with a strong velocity gradient $(4.5-7.0$

$378 \mathrm{~km} / \mathrm{s}$ ) and a second crustal layer $4 \mathrm{~km}$ thick and a small velocity gradient around 7.6

$379 \mathrm{~km} / \mathrm{s}$. West of $12^{\circ} 40^{\prime} \mathrm{W}$ the crust is clearly oceanic, with a $2 \mathrm{~km}$ thick upper layer with

380 velocities $4.5-6.5 \mathrm{~km} / \mathrm{s}$ over a lower layer of $3.5-4.5 \mathrm{~km}$ and seismic velocities of 6.7 to

$3817.2 \mathrm{~km} / \mathrm{s}$.

382

383 In front of NW Iberia, the morphology of the margin is complex with, from East to

384 West, a small continental platform, a large basin about $100 \mathrm{~km}$ wide (Galicia Interior

385 Basin) where the Moho depth thins to $15 \mathrm{~km}$, a structural high (Galicia Bank) where the 386 Moho deepens to $22 \mathrm{~km}$ to thin again smoothly towards west to a minimum of $10 \mathrm{~km}$

387 eastwards of the peridotitic ridge (located at around $12.5^{\circ} \mathrm{W}$ ). West of this ridge, the 388 crustal structure is typical of oceanic domains (Whitmarsh et al., 1990, Murillas et al., 389 1990, Pérez-Gussinyé et al., 2003).

390

391 The structure beneath the North Iberian or Cantabrian margin has important lateral

392 variations. In the western sector the transition is marked by a rapid and smooth thinning 393 of the crust, from $30 \mathrm{~km}$ on land to $15 \mathrm{~km}$ in the abyssal plain the Bay of Biscay. MCS

394 profiling has suggested the presence there of oceanic crust, interpreted as an arrested 395 subduction (Álvarez-Marrón et al., 1996, Ayarza et al., 2004). In the central part of the 396 margin the inferred models show the indentation of the Cantabrian margin crust 397 between the middle and lower Iberian crust. The Moho depth shifts abruptly from more 398 than $45 \mathrm{~km}$ to $30 \mathrm{~km}$ beneath the shoreline and then thins smoothly till $18-20 \mathrm{~km}$ 
399 (Fernández-Viejo et al., 1998). The N-S and E-W profiles acquired during the

400 MARCONI experiment in the eastern half of the margin show an important crustal

401 thinning to the NW part of the study area, where the Moho is located at depths of 10-14

$402 \mathrm{~km}$ and the velocities in the upper and lower crust are, respectively, lower and higher

403 than expected, depicting an elongated and thinned transitional crust. Towards the 404 eastern termination of the North Iberian margin, the crust is clearly of continental type 405 (Ruiz, 2007).

407 Summary of results: crustal transects and Moho-depth model

409 The velocity-depth distribution along three illustrative transects crossing the Iberian 410 Peninsula and its margins is sketched in Figure 2. The location of these transects has 411 been chosen to follow, as much as possible, the profiles where direct crustal modelling 412 is available. We use them to compile and discuss the main crustal parameters beneath 413 Iberia. Figure 2a shows a transect oriented NNW-SSE from the Bay of Biscay to the 414 African coast, sampling the thinned continental crust of the abyssal plain, the crustal 415 imbrication related to the Alpine compression beneath the Cantabrian Mountains, the 416 typical Iberian Massif crust and the significant crustal thickening beneath the Internal 417 Betics, followed by the crustal thinning beneath the Alboran Sea. The second transect 418 (Figure 2b) is oriented grossly E-W along the northern part of Iberia. It samples the 419 eastern termination of the Iberian Abyssal Plain, with a typical oceanic crustal structure, 420 and goes through the Galicia Margin, crossing the peridotitic ridge, the Galicia Bank, 421 the Galicia Interior Basin and the continental platform. On land, the transects samples 422 the Iberian Massif units and depicts clearly the transition to the areas affected by the 423 Alpine orogeny, with crustal thicknesses reaching almost $50 \mathrm{~km}$ along the Cantabrian- 
424 Pyrenean range. Locally, intrusions of the European-Cantabrian lower crust and

425 thinning beneath the Basque-Cantabrian basin are observed. At the eastern end of the

426 Pyrenees, the crust thins once the extended domains of the Western Mediterranean are 427 reached. The third transect presented here (Figure 2c) is also oriented E-W but sampling 428 the central part of Iberia. Its western termination shows the Atlantic oceanic crust. It 429 crosses afterwards the typical non-volcanic passive margin of Iberia, and reaches the

430 Iberian Massif units. Eastwards, the transect evidences the local crustal thickenings 431 beneath the Central System and the Iberian Chain, and it illustrates the transition to the

432 Valencia Trough, an area of clearly extended, thinned continental crust and it ends by 433 documenting the thicker crust beneath the Balearic Promontory.

435 In order to obtain a Moho-depth model for the overall area, we have first compiled the 436 geographical location of the published wide-angle and multichannel seismic profiles 437 that provide information about the whole crustal structure beneath Iberia and its 438 surrounding waters. In some cases, especially for the oldest experiments, the 439 coordinates of the profiles have been recovered directly from the published maps and 440 therefore may involve some degree of inaccuracy (Figure 1). The next step has been to 441 retrieve the Moho depths along the published profiles; if the profile was interpreted 442 assuming a 1D velocity-depth distribution, the reported Moho-depth is adopted along 443 the profile. If $2 \mathrm{D}$ models where available, the Moho depth was extracted for enough 444 points to take care of its topographic variations. About 320 points have been compiled 445 in this way, stretching E-W from the Atlantic oceanic crust to the Balearic Promontory 446 and N-S from the thinned crust of the Bay of Biscay to the African coast of Morocco, 447 with a mean density of about one measurement every $0.5^{\circ} \times 0.5^{\circ}$. The final compilation is 
448 presented in Figure 3 and is also presented as an electronic table as complementary

449 material.

450

451 As a final step, we undertake the construction of a Moho-depth model using ordinary 452 kriging as the interpolation method. This method has the advantage to take into account 453 the knowledge of the spatial continuity of the variable to estimate. Each data point is 454 weighted in the kriging procedure with a coefficient which takes care of the distance to 455 the neighbour points. To obtain these coefficients, the spatial autocorrelation in the form 456 of semi-variograms of the available data is computed and modelled. This procedure tries 457 to ensure a correct weighting function for not-uniform data distributions. We have used 458 the KT3D code, a part of the GSLIB package (Deutsch and Journal, 1998). The semi459 variogram for the Moho-depth distribution has been modelled using a spherical model 460 with a sill located at $70 \mathrm{~km}^{2}$ beyond a range of $3^{\circ}(325 \mathrm{~km})$. The variograms along 461 different directions show some evidences of spatial anisotropy, but we decided not to 462 retain this contribution into the final model to avoid overmodelling, as the data are not 463 conclusive in this respect. The final grid, spatially filtered and plotted using the GMT 464 software package (Wessel and Smith, 1998), is presented in Figure 4 and can be 465 downloaded in netCDF format at http://www.ija.csic.es/gt/jd/Moho_Iberia. It must be 466 pointed out that for some regions, in particular at the transition from the Pyrenees chain 467 to the Iberian Ranges through the Ebro Basin, or at the limit between the Guadalquivir 468 basin and the Betics and in the SW Mediterranean Sea, the interpolated Moho-depths 469 may not reflect correctly the real crustal thicknesses, because experimental data is very 470 scarce in these areas.

471

472 


\section{Discussion and Conclusions}

474

475 The lithosphere of the Iberian Peninsula and its surrounding waters has been sampled 476 from a huge number of active seismic experiments during the last three decades. 477 However, a specific compilation of its seismic crustal features has not been attempted 478 since about 20 years, and a great amount of results and constraints is available since 479 then. We have revisited here all these seismic reflection and refraction experiments to 480 summarize main crustal parameters and to build up a comprehensive map of crustal 481 thicknesses by compiling Moho depths. We came up with a geo-referred database that 482 has then been interpolated using kriging algorithms to obtain a continuous Moho depth 483 model, in the form of a regular grid file. We took care that in this map the geographical 484 areas readily sampled by the profiles and those where the final model comes from 485 interpolation are well recognized.

487 One of the most significant features established since long ago is the crustal thickening, 488 reaching $50 \mathrm{~km}$ depth, beneath the Pyrenean range. However, the experiments 489 performed in North Iberia in the last 10 years have revealed that this thickened crust is not limited to the Pyrenees, but extends westwards along the Cantabrian Mountains, up

491 to the contact with the Iberian Massif units at about $6^{\circ} \mathrm{W}$, a feature that is not stated in 492 previous regional or global crustal depth compilations (Meissner, 1986, Dezes and 493 Ziegler, 2000). In the Betics, a thickening reaching $38 \mathrm{~km}$ is also observed, but seems to 494 be limited to a small area beneath the Internal Betics. The Iberian Chain, oriented NE495 SW south of the Ebro Basin, has also a crustal root reaching $40 \mathrm{~km}$ at its $\mathrm{SE}$ part. The 496 extension to the NW of this root needs still to be investigated. The northern part of the 497 Iberian Massif shows Moho depths between 32 and $40 \mathrm{~km}$, illustrating the transition to 


\section{$-21-$}

498 the thickened Alpine areas. Thicknesses of about 31-32 km have been reported at the

499 central and southern areas of the Variscan domains, even if recent high density

500 experiments suggest that the crust is slightly thicker in the southwestern zone, reaching

501 probably $33-34 \mathrm{~km}$.

502

503 The Valencia Trough and the Alboran Sea show a clear thinning related to the large

504 scale extensional tectonics that affected those areas. The connection between both

505 domains has still to be established, and it is an objective of some ongoing projects. The

506 Atlantic margins illustrate the transition between the oceanic crust, where the Moho is

507 located at $10-14 \mathrm{~km}$, to the continental domain, with depths exceeding $31 \mathrm{~km}$. In

508 southern and central Iberia this transition appears quite smooth, depicting the

509 characteristics of a typical non-volcanic passive margin. In front of Galicia (NW Iberia)

510 the morphology of the margin is more complex, due to the presence of the extended

511 Galicia Interior Basin and the peridotitic ridge, a fact that is also missing in previous

512 compilations. Finally, the North Iberian margin shows a great east-west variation. In its

513 Western part, the image is similar to the West Atlantic margin, with a rather smooth

514 transition from the continental crust on land to the oceanic crust in the abyssal plain of

515 the Bay of Biscay. In the central part of the margin the image is similar to that of the

516 Pyrenean range, with crustal imbrication and thickening beneath the shoreline. In the

517 eastern half of the basin, the seismic properties suggest an elongated and thinned

518 transitional crust towards the centre of the abyssal plain, without evidences for oceanic

519 crust. At the eastern termination of the margin, in the Aquitanian platform, the crust is

520 also thinned but preserves the usual continental properties. 


\section{$-22-$}

522 At an overall scale, a clear anticorrelation is observed between the topographic and

523 Moho depth profiles (see Figure 2), reflecting what would be expected if the crust was

524 compensated following the Airy hypothesis. However, differences between the Moho 525 depths from DSS profiles and the isostatic Moho depths can locally reach up to $10 \mathrm{~km}$ 526 beneath some thickened (Pyrenees) or thinned (Valencia Trough) regions.

528 The consistency of the crustal depth results compiled here from active seismic profiles

529 can be checked with respect to results from other independent seismic methods, such as

530 surface waves or receiver functions. Published works related to dispersion of surface

531 waves (ex. Badal et al. 1993, Corchete et al., 1995) focus in obtaining large scale mantle

532 tomographic images and do not properly constrain the base of the crust. The same

533 happens with continental-scale studies (ex. Peter et al., 2008). More recent works use

534 surface wave analysis to infer models of the uppermost part of the crust, either from

535 earthquakes (p.e. Chourak et al., 2003) or from seismic noise (Villaseñor et al., 2007),

536 but the corresponding models do not extend to Moho depths. On the other hand,

537 estimations of the crustal thickness beneath some areas in Spain have been inferred

538 from teleseismic Receiver Functions (RF) analyses. Using pseudo-migration of RFs,

539 Díaz et al., (2003) imaged the base of the crust in a couple of lithospheric transects

540 located beneath the western termination of the Pyrenees and the Cantabrian Mountains.

541 Later on, the same authors extended the work to NW Iberia (Díaz et al, 2008). In all

542 cases, the depth of the base of the crust is remarkably coincident with the results from

543 DSS profiles. Julià and Mejia (2004) presented local estimates of crustal thicknesses,

544 obtained using the H-K stacking method, for 10 stations in Iberia. More recently,

545 Mancilla et al. (2008) presented first results of a similar study in Southern Iberia using a

546 dense network of stations. In most cases, the differences between the crustal thicknesses 


\section{$-23-$}

547 presented in our compilation and the RF estimations do not exceed $2 \mathrm{~km}$, hence

548 documenting the consistency of the results inferred from two independent seismic

549 methodologies.

550

551 The integrative Moho map we have derived for this key area in the Western

552 Mediterranean can contribute to constrain further regional studies documenting the 553 interaction between European and African plates, either at crustal, lithospheric or

554 mantle scales. The bibliographic effort needed to compile all the information used here

555 will serve in establishing a database of active seismic experiments beneath Iberia, to be

556 integrated in large-scale geosciences projects such as the ongoing Spanish Topo-Iberia 557 or the coming ESF-TopoEurope ones.

558

559 Acknowledgements

560 This is a contribution of the Team Consolider-Ingenio 2010 TOPO-IBERIA (CSD2006-

561 00041). Additional founding provided by Generalitat de Catalunya (2005SGR00874)

562 and by SIBERIA project (CGL2006-01171).

563

564 References

565

566 Álvarez-Marrón, J., Pérez-Estaún, A. Dañobeitia, J.J., Pulgar, J.A., Martínez-Catalán,

567 J.R., Marcos, A., Bastida, F., Ayarza, P., Aller, J., Gallart, J., González-Lodeiro, F.,

568 Banda, E., Comas, M.C. and CórdobA, D., (1996). Seismic structure of the northern

569 continental margin of Spain from ESCIN deep seismic profiles. Tectonophysics, 264, $570 \quad 153-174$. 


\section{$-24-$}

572 Ayarza, P., Martínez Catalán, J. R., Gallart, J., Pulgar, J.A. and Dañobeitia, J.J., (1998).

573 ESCIN 3.3: A seismic image of the Variscan crust in the hinterland of the NW Iberian

574 Massif. Tectonics, 17 (2), 171-186.

575

576 Ayarza, P., Martínez Catalán, J.R., Zeyen, H., Juhlin, C., and Alvarez Marrón, J. (2004).

577 Geophysical constraints on the deep structure of a limited ocean-continent subduction zone 578 at the North Iberian Margin. Tectonics, 23, TC1010

579

580 Badal,J ., V. Corchete, G. Payo,J . A. Canas, and L. Pujades (1993). Shear-wave velocity

581 structure below the Iberian Peninsula as obtained by a detailed analysis of surface

582 waves. Tectonophysics2,2 5, 167-190, 1993.

583

584 Banda, E. (1988). Crustal parameters in the Iberian Peninsula. Phys. Earth Planet. Inter.,

$585 \quad 51,222-225$

586

587 Banda, E. and Ansorge, J. (1980). Crustal structure under the central and eastern part of

588 Betic Cordilleras. Geophys. J. R. Astron. Soc. 63, 515-532

589

590 Banda, E., Ansorge, J., Boloix M. and Córdoba, D., (1980). Structure of the crust and

591 upper mantle beneath the Balearic Islands (western Mediterranean). Earth planet. Sci.

592 Lett., 49, 219-230.

593

594 Banda, E., Suriñach, E., Aparicio, A., Sierra, J. and Ruiz De La Parte, E., (1981). Crust

595 and upper mantle structure of the central Iberian Meseta (Spain). Geophys. J. R. astr.

596 Soc., 67, 779-789. 
598 Banda, E., Udias, A., Mueller, St., Mezcua, J., Boloix, M., Gallart, J. and Aparicio, A.

599 (1983) Crustal structure beneath Spain from deep sounding experiments. Phys. Earth

600 Planet. Inter., 31, 277-280

601

602 Banda, E., Gallart, J., Garcia-Dueñas, V., Dañobeitia, J.J. and Makris, J. (1993). Lateral

603 variation of the crust in the Iberian Peninsula. New evidence from the Betic Cordillera.

604 Tectonophysics, 221, 53-66.

605

606 Banda, E., Torné, M., and Iberian Atlantic Margins Group, (1995). Iberian Atlantic

607 Margins Group investigates deep structure of ocean margins. Eos Trans. AGU 76(3):

$608 \quad 25,28-29$.

609

610 Barranco, L.M., J. Ansorge and E. Banda, (1990). Seismic refraction constraints on the

611 geometry of the Ronda peridotitic massif (Betic Cordillera, Spain). Tectonophysics,

$612184,3-4,379-392$

613

614 Beslier, M.O., Ask, M. and Boillot, G., (1993). Ocean-continent boundary in the Iberia

615 Abyssal Plain from multichannel seismic data. Tectonophysics, 218, 4, 383-393.

616

617 Bois, C. and Gariel, O. (coord.), (1997). ECORS Bay of Biscay survey. Mem. Soc.

618 Geol. Fr, 171. Paris.

619 Booth-Rea, G., Ranero, C.R., Martínez-Martínez, J.M. and Grevemeyer, I., (2007).

620 Crustal types and Tertiary tectonic evolution of the Alboran sea, western Mediterranean.

621 Gochemistry Geophysics Geosystems, 8, 10 doi:10.1029/2007GC001639 
622 Carbonell, R., Pérez Estaún, A., Simancas, J.F., Juhlin, Ch., Pous, J., González Loreiro,

623 F., Muñoz, G., Heise, W., and Ayarza, P. (2004). Geophysical evidence of a mantle

624 derived intrusion in SW Iberia. Geophysical Research Letters 31, L11601-04.

625 Carbonell, R., Simancas, F., Martinez-Poyatos, D., Ayarza, P., Gonzalez, P., Tejero, R.,

626 Martín-Parra, L., Matas, J., Gonzalez-Lodeiro, F., Pérez-Estaún, A., García-Lobon, J.,

627 Mansilla, L. and Palomeras, I., (2007). Seismic Reflection Transect across the Central

628 Iberian Zone (Iberian Massif): The ALCUDIA project. EOS Trans. AGU 88(52), Fall

629 Meeet. Suppl., Abstract T31B-0479.

630

631 Chian, D., Louden, K.E., Minshull, T.A. and Whitmarsh, R.B., (1999). Deep structure

632 of the ocean-continent transition in the southern Iberia Abyssal Plain from seismic

633 refraction profiles: Ocean Drilling Programme (Legs 149 and 173) transect. J. Geophys.

634 Res., 104, 7443-7462.

635

636 Chourak, M., Corchete, V. Badal, J., Serón, F. and Gómez, F. (2003) Imaging of the

637 Near-Surface shear-velocity structure of the Granada basin (Southern Spain). B.S.S.A., $63893,1,430-442$.

639

640 Choukroune, P. and Ecors-Pyrenees Team.(1989). The ECORS Pyrenean deep seismic

641 profile. Reflection data and the overall structure of an orogenic belt. Tectonics, 8, 1, 23-39.

642

643 Choukroune, P., F. Roure, B. Pinet and ECORS Pyrenees Team, (1990). Main results of

644 the ECORS Pyrenees profile. Tectonophysics, 173, 1-4, 20, 411-418.

645 
646 Collier, J.S., Buhl, P., Torne, M. and Watts, A.B. (1994). Moho and lower crustal

647 reflectivity beneath a young rift basin: Results from a two-ship, wide-aperture seismic

648 reflection experiment in the Valencia trough (western Mediterranean). Geophys. J. Int., $649118,159-180$.

650

651 Comas, M., Soto, J.I., Talukder, A.R:, Campos, J., Martinez-Martinez, J.M., Sanchez-

652 Gomez, M. and Romas-Alpiste, M.J., (2004). Aftermath of extension and compression 653 in the Alboran Basin evolution: unraveling tectonic evidence from new MCS images.

654 Geophys. Res. Abst., 6, 065078.

655

656 Comas, M., and MARSIBAL 1-06 Scientific Party (2007). Preliminary results of 657 Marsibal 1-06 cruise in the Alboran and western Algero-Balearic basins. Geophys. Res. 658 Abst., 9, 10871.

659

660 Corchete , V., Badal, J., Serón, J.F. and Soria, A. (1995). Tomographic images of the 661 Iberian subcrustal lithosphere and asthenosphere. J Geophys Res., 100, 24133-24146. 662

663 Córdoba, D., E. Banda And J. Ansorge, (1987). The Hercynian crust in northwestern 664 Spain: a seismic survey. Tectonophysics, 132, 4, 321-333.

665

666 Córdoba, D., Banda, E. and Ansorge, J. (1988). P-wave velocity-depth distribution in 667 the Hercynian crust of Northwest Spain. Phys. Earth Planet. Inter., 51, 235-248.

668

669 Daignières, M., Gallart, J. and BandA, E. (1981). Lateral variation of the crust in the 670 North Pyrenean Zone. Annales Geophysique, 37, 3, 435-456. 
672 Daignières, M., M. Séguret, M. Specht and ECORS Team, (1994). The Arzacq-Western

673 Pyrenees ECORS Deep Seismic Profile. In: Mascle, A. (ed). Hydrocarbon and

674 Petroleum Geology of France. Eur. Assoc. Pet. Geosci. Spec. Publ., vol. 4, Springer-

675 Verlag, New York. 199-208

676

677 Daignières, M., Gallart, J., Hirn, A. and Suriñach, E. (1998). Complementary

678 geophysical surveys along the ECORS Pyrenees line. Mem Soc Geol. Fr., 173, 55-80.

679

680 Dañobeitia, J.J., Arguedas, M., Gallart, J., Banda, E. and Makris, J. (1992). Deep seismic

681 configuration of the Valencia Trough and its Iberian and Balearic borders from extensive

682 refraction-wide angle reflection seismic profiling. Tectonophysics, 302, 37-55.

683

684 Damotte, B. (coord.) (1998). The Ecors Pyrenean Deep Seismic Surveys, 1985-1994,

685 Mem. Soc. Geol. Fr, 173, Paris.

686

687 Dean, S.M., Minshull, T.A., Whitmarsh, R.B. and Louden, K., (2000). Deep structure of

688 the ocean-continent transition in the southern Iberia Abyssal Plain from seismic

689 refraction profiles: II The IAM-9 transect at $40^{\circ} 20^{\prime}$ N. J. Geophys. Res., 105, 5859-

6905886.

691

692 Deutsch, C.V. and Journal, A.G., 1988. GSLIB - Geostadistical Software Library and 693 User's Guide. Oxford University Press, Oxford.

694 


\section{$-29-$}

695 Dèzes, P. and Ziegler, P. A., 2001: European Map of the Mohorovicic discontinuity.

696 2nd EUCOR-URGENT Workshop (Upper Rhine Graben Evolution and Neotectonics),

697 Mt. St. Odile, France.

698

699 Díaz, J., Gallart, J., Cordoba, D., Senos, L., Matias, L., Suriñach, E., Hirn, A., Maguire, P.

700 and Iliha Dss Group (1993a). A deep seismic sounding investigation of lithospheric

701 heterogeneity and anisotropy beneath the Iberian Peninsula. Tectonophysics, 221, 35-51.

702

703 Díaz, J., Hirn, A., Gallart, J. and Senos, L. (1993b). Evidences for azimuthal anisotropy in

704 SW Iberia from DSS data. Physics of the Earth and Planetary Interiors, 78, 193-206.

705

706 Díaz, J., Gallart, J., Pedreira, D., Pulgar, J.A., Ruiz, M., Lopez, C. and González-

707 Cortina, J.M. (2003). Teleseismic imaging of alpine crustal underthrusting beneath

708 Niberia Geophys. Research Letters,30,11,doi: 10.1029/2003GL017073.

709

710 Díaz, J., Gallart, J., Gaspà, O., Ruiz, M. and Córdoba, D. (2008). Seismicity analysis at

711 the 'Prestige' oil-tanker wreck area (Galicia Margin, NW of Iberia). Marine Geology,

712 doi:10.1016/j.margeo.2007.09.015

713

714 Díaz, J., J. Gallart, J.A. Pulgar, M. Ruiz, O. Gaspà, C. López and J.M. González-

715 Cortina (2008). Crustal structure beneath North-West Iberia imaged using receiver

716 functions. Geophysical Research Abstracts, 10.

717 


$$
-30-
$$

718 ECORS Pyrenean Team (1988). The ECORS deep reflection seismic survey across the

719 Pyrenees. Nature, 331, 508-511.

720

721 Fahlquist, D.A., (1963). Seismic refraction measurements in the Western Mediterranean

722 Sea. Ph. Thesis, Massachusetts Institute of Technology, Cambridge, Mass., 173pp.

723

724 Fernández-Viejo, G., Gallart, J., Pulgar, J.A., Gallastegui, J., Dañobeitia, J.J. and Cordoba, 725 D. (1998). Crustal transition between continental and oceanic domains along the North

726 Iberian Margin from wide-angle seismic and gravity data. Geophysical Research Letters, $727 \quad 25,4249-4252$.

728

729 Fernández-Viejo, G., Gallart, J., Pulgar, J.A., Cordoba, D. and Dañobeitia, J.J. (2000).

730 Seismic signatures of Variscan and Alpine tectonics in NW Iberia: crustal structure of the

731 Cantabrian Mountains and Duero basin. J. Geophys. Res., 105, 3001-3018.

732

733 Gallart, J., Daignières, M., Banda, E., Suriñach, E. and Hirn, A. (1980). The Eastern

734 Pyrenean domain: lateral variations at crust-mantle level. Annales Geophysique, 36, 2, $735 \quad 141-158$.

736

737 Gallart, J., Banda, E. and Daignieres, M. (1981). Crustal structure of the Paleozoic

738 Axial Zone of the Pyrenees and transition to the North Pyrenean Zone. Annales

739 Geophysique, 37, 3, 457-480.

740 


\section{$-31-$}

741 Gallart, J., Rojas, H., Díaz, J. and Dañobeitia, J.J., (1990). Features of deep crustal

742 structure and transition offshore-onshore at the Iberian flank of the Valencia Trough

743 (Western Mediterranean). Journal of Geodynamics, 12, 233-252.

744

745 Gallart, J., Vidal, N. and Dañobeitia, J.J. (1994a). Lateral variations in the deep crustal

746 structure at the Iberian margin of the Valencia trough imaged from seismic reflection

747 methods. Tectonophysics, 232, 59-75.

748

749 Gallart, J., Dañobeitia, J.J., Díaz, J. And Vidal, N. (1994b). Crustal heterogeneities at the

750 NW Alboran sea and its transition to the Betics. XIX ${ }^{\text {th }}$ European Geophysical Society.

751 Grenoble

752

753 Gallart, J., Vidal, N. and Dañobeitia, J.J. (1995). Multichannel seismic image of the crustal

754 thinning at the NE Iberian margin combining normal and wide angle reflection data.

755 Geophysical Research Letters, 22, 4, 489-492.

756

757 Gallart, J., Díaz, J., Vidal, N. and Dañobeitia, J.J. (1995). The base of the crust at the

758 Betics-Alboran Sea transition: evidence for an abrupt structural variation from wide-

759 angle ESCI data. Revista Sociedad Geológica España, vol. 8 (4), 519-528

760

761 Gallart, J., Díaz, J., Nercessian, A., Mauffret A. and Dos Reis, T. (2001). The eastern end

762 of the Pyrenees: seismic features at the transition to the NW Mediterranean. Geophysical

763 Research Letters, 28 (11) 2277-2280.

764 
765 Gallart, J., Salas, R., Guimerà, J., Mas, R., Díaz, J. and Ruiz, M., (2004). A

766 refraction/wide-angle reflection seismic profile through the Iberian Chain: preliminary

767 report. Geo-Temas, 6, (2), 183-186.

768

769 Gallart, J., Díaz, J. and Córdoba, D. (2006). Investigando la estructura litosférica en la

770 Península Ibérica y sus márgenes: tres décadas de perfiles sísmicos profundos. Física de

771 la Tierra, 18, 69-96.

772

773 Gallastegui, J., Pulgar, J.A. and Alvarez-Marrón, J. (1997). 2-D seismic modeling of the

774 Variscan Foreland Thrust and Fold Belt crust in NW Spain from ESCIN-1 deep seismic 775 reflection data. Tectonophysics, 269, 21-32.

776

777 Gallastegui, J. Pulgar, J. and Gallart, J., (2002). Initiation of an active margin at North

778 Iberian continent-ocean transition. Tectonics, 21 (4), 15-1 a 15-14.

779

780 Galvé, A., Gallart, J., Díaz, J., Fernández, M., Grevemeyer, I., Ranero, C.R. and the

781 WestMed Team (2007). Probing the deep structure of the Eastern Alboran Basin

782 (Western Mediterranean) by wide-angle seismics. Geophys. Res. Abstracts, Vol. 9, 783 A0346.

784 García-Dueñas, V., E. Banda, M. Torné, D. Córdoba and Esci-Béticas Working GrouP 785 (1994). A deep seismic reflection survey across the Betic Chain (southern Spain): first 786 results. Tectonophysics, 232, 77-89 


\section{$-33-$}

787 González, A., Torné, M., Córdoba, D., Vidal, N., Matias, L. and Díaz, J. (1996). Crustal

788 thinning in the Southwestern Iberian Margin. Geophysical Research Letters vol. 23

789 (18), 2777-2480.

790

791 González, A., Córdoba, D., Vegas, R. and Matias, L.M., (1998). Seismic crustal

792 structure in the southwest of the Iberian Peninsula and the Gulf of Cádiz.

793 Tectonophysics, 296, 317-331.

794

795 González, A., Córdoba, D. and Vales, D. (1999). Seismic structure of Galicia continental

796 margin, NW Iberian Peninsula. Geophys. Res. Lett., vol. 26, No.8, pp 1061-1064.

797

798 González-Fernández, A., Córdoba, D., Matías, L.M. and M. Torné. (2001). Seismic crustal

799 structure in the Gulf of Cadiz (SW Iberian Peninsula). Marine Geophysical Researches, 22,

$800 \quad 207-223,2001$

801

802 Groupe Galice, (1979). The continental margin off Galicia and Portugal: acoustical 803 stratigraphy, dredge stratigraphy and structural evolution. In: Sibuet, Ryan et al., Init. 804 Repts. DSDP 47 (2), 633-622.

805 Hatzfeld, D. and D. Ben Sari, (1977). Grands profils sismiques dans la région de l'Arc 806 de Gibraltar. Bull. Soc. Géol. Fr. 7 749-756.

807 Henning, A.T. and Sawyer, D.S., (2004). Exhumed upper mantle within the ocean808 continent transition on the northern West Iberia margin: Evidence from prestack depth 809 migration and total tectonic subsidence analyses. J. Geophys. Res., 109, B05103, doi: $810 \quad 10.1029 / 2003 J B 002526$. 
812 Hinz, K., (1973). Crustal structure of the Balearic sea. Tectonophysics, 20, 1-4, 295-

$813 \quad 302$.

814 Julià J. and Mejía, J. Thickness and Vp/Vs ratio variation in the Iberian Crust. (2004)

815 Geophys., J. Int, 156, 59-72.

816

817 Laske, G., Masters, G. and Reif, C. (2001) CRUST 2.0: A New Global Crustal Model at

818 2x2 Degrees. http://mahi.ucsd.edu/Gabi/rem.html

819

820 Mancilla, F; Dündar, S.; Kind, R.; Morales, J.; Li, X.; Julià, J. (2008) A preliminary

821 receiver function investigation of the crustal structure in the Iberia-Africa plate

822 boundary. Geophysical Research Abstracts, 10.

823

824 Marillier, F., A. Tomassino, Ph. Patriat and B. Pinet, (1988). Deep structure of the

825 Aquitaine Shelf: constraints from expanding spread profiles on the ECORS Bay of

826 Biscay transect, Marine and Petroleoum Geology, 5, 65-74.

827

828 Mauffret, A. and Montadert, L., (1988). Seismic stratigraphy off Galicia. In: Boillot,

829 Winterer et al., Proc Init. Rep. ODP, 10 (B):13-20.

830

831 Mauffret, A., B. Durand De Grossouvre, A. Tadeu Dos Reis, Ch. Gorini and A.

832 Nercessian, (2001). Structural geometry in the eastern Pyrenees and western Gulf of

833 Lion (Western Mediterranean). Journal of Structural Geology, 23, 11, 1701-1726.

834 


\section{$-35-$}

835 Medialdea, T., E. Suriñach, R. Vegas, E. Banda and J. Ansorge, (1986). Crustal

836 structure under the western end of the Betic Cordillera (Spain). Annales Geophysicae, 4,

$837 \quad 457-464$

838

839 Medialdea, T., R. Vegas, L. Somoza, J. T. Vázquez, A. Maldonado, V. Díaz-Del-Río,

840 A. Maestro, D. Córdoba and M. C. Fernández-Puga, (2004). Structure and evolution of

841 the "Olistostrome" complex of the Gibraltar Arc in the Gulf of Cádiz (eastern Central

842 Atlantic): evidence from two long seismic cross-sections. Marine Geology, 209, 1-4,

$843 \quad 173-198$.

844

845 Meissner, R. (Ed.) (1986). The continental crust, a geophysical approach. International

846 Geophysics Series, vol. 34. Academic Press.

847

848 Mendes-Victor, L.A., Simoes, J.Z. and Matias, L., (1988). The program of deep seismic

849 in Portuguese mainland. In: E. Banda and P. Santanach (Eds), Proc. $5^{\text {th }}$ Workshop on

850 the European Geotraverse (EGT), the Iberian Peninsula, European Science Foundation,

851 Strasbourg, 13-21.

852

853 Mueller, S., C. Prodehl, A. S. Mendes and V. Sousa Moreira, (1973). Crustal structure

854 in the southwestern part of the Iberian Peninsula. Tectonophysics, 20, 1-4, 307-318.

855

856 Murillas, J., Mougenot, D. Boillot, G. Comas, M.C., Banda, E. and Mauffret, A.,

857 (1990). Structure and evolution of the Galicia Interior Basin (Atlantic western Iberian

858 continental margin). Tectonophysics, 184, 297-319.

859 


\section{$-36-$}

860 Nercessian, A., Mauffret, A., Dos Reis, T., Vidal, N., Gallart, J. and Díaz, J. (2001). Deep

861 reflection seismic images of the crustal thinning in the eastern Pyrenees and western Gulf

862 of Lion. Journal of Geodynamics, 31 (2) 211-225.

863

864 Palomeras, I., Carbonell, R., Flecha, I., Simancas, F., Ayarza. P., Martin, J., Martinez-

865 Poyatos, D., Azor, A., González-Lodeiro, F. and Pérez-Estaún, A. (2008). Constraints on

866 the lithosphere across the Variscan orogen of SW Iberia from dense wide-angle seismic

867 refraction data. Journal of Geophysical Research, submitted.

868

869 Pascal, G., M. Torné, P. Buhl, A. B. Watts and A. Mauffret, (1992). Crustal and

870 velocity structure of the Valencia trough (western Mediterranean), Part II. Detailed

871 interpretation of five Expanded Spread Profiles. Tectonophysics, 203, 1-4, 21-35

872

873 Pedreira, D., Pulgar, J.A., Gallart, J. and Díaz, J., (2003). Seismic evidence of Alpine

874 crustal thickening and wedging from the Western Pyrenees to the Cantabrian Mountains

875 (North Iberia). Journal of Geophysical Research, 108 (B4) pp. ETG 10-1 to ETG 10-21

$876 \quad 10.1029 / 2001 J B 001667$

877

878 Pedreira, D., Pulgar, J.A., Gallart, J. and Torne, M. (2007). 3-D Gravity and magnetic

879 modelling of crustal indentation and wedging between the Iberian and European plates in

880 the western Pyrenees-Cantabrian Mountains. Journal of Geophysical Research, 112,

881 B12405, doi:10.1029/2007JB005021

882 


\section{$-37-$}

883 Pérez-Estaún, A., Pulgar, J.A. Banda, E., Álvarez-Marrón, J. and Esci-N Research

884 Group (1994). Crustal structure of the external variscides in northwest Spain from deep

885 seismic reflection profiling. Tectonophysics, 232, 91-118.

886

887 Pérez-Gussinyé, M., Ranero, C.R. and Reston, T.J. (2003). Mechanisms of extension at 888 nonvolcanic margins: Evidence from the Galicia Interior Basin, west of Iberia. J.

889 Geophys. Res., 108,B5, 2245, doi: 10.1029/2001JB000901.

890

891 Peter, D., Boschi, L., Deschamps, F. Fry, B. Ekstrom, G. and Giardini, D. (2008). A

892 new finite-frequency shear-velocity model of the European-Mediterranean region.

893 Geophys. Res., Let., 35, L16315, doi:10.1029/2008GL034769.

894

895 Pickup, S. L. B., R. B. Whitmarsh, C. M. R. Fowler, and T. J. Reston (1996). Insight

896 into the nature of the ocean-continent transition off West Iberia from a deep

897 multichannel seismic reflection profile. Geology, 24(12):1079-108.

898

899 Pinheiro, L.M., Whitmarsh, R.B. and Miles, P.R., (1992). The ocean-continent

900 boundary off the western continental margin of Iberia-II. Crustal structure in the Tagus

901 Abyssal Plain. Geophys. J. Int., 109, 106-124.

902 Pulgar, J.A., Gallart, J., Fernandez-Viejo, G., Perez-Estaun, A., Alvarez-Marron, J. and

903 Escin Group, (1996). Seismic image of the Cantabrian Mountains in the western extension

904 of the Pyrenean belt from integrated reflection and refraction data. Tectonophysics, 264,1905 19. 
906 Purdy, G.M., (1975). The eastern end of the Azores-Gibraltar plate boundary. Geophys.

907 J. R. astr. Soc., 43, 973-1000.

908

909 Ruiz, M., (2007). Caracterització estructural i sismotectònica de la litosfera en el domini

910 Pirenaico-Cantàbric a partir de métodes de sísmica activa i pasiva, $\mathrm{Ph}$. Thesis, Univ.

911 Barcelona. 353 pp.

912

913 Simancas, F., González-Lodeiro, A., Jhulin, P., Ayarza, A., Carbonell, R., Kashubin, A.,

914 Azor, D., Martínez-Poyatos, G.R., Almodovar, E., Pascual, R., Saenz and Expósito, I.

915 (2003). Crustal structure of the transpressional Variscan orogen of SW Iberia: SW

916 Iberia deep seismic reflection profile (IBERSEIS). Tectonics, 22, 6, 1962.

917

918 Villaseñor, A., Y.Yang, M. H. Ritzwoller, and J. Gallart (2007). Ambient noise surface

919 wave tomography of the Iberian Peninsula: Implications for shallow seismic structure.

920 Geophys. Res. Lett., 34, L11304, doi:10.1029/2007GL030164

921

922 Sousa Moreira, V., Mueller, St. Mendes, A.S. and Prodehl, C. (1978). The deep

923 structure of southern Portugal. In: Geodinámica de la Cordillera Bética y Mar de

924 Alborán. University of Granada, 35-41.

925

926 Suriñach, E. and R. Vegas, (1988) .Lateral inhomogeneities of the Hercynian crust in

927 central Spain. Phys. of the Earth and Planetary Interiors, 51, 1-3, 226-234.

928

929 Suriñach, E., Marthelot, J.M., Gallart, J., Daignieres, M. and Hirn, A. (1993). Seismic

930 images and evolution of the Iberian crust in the Pyrenees. Tectonophysics, 221, 67-80. 
932 Téllez, J. and Córdoba, D. (1998). Crustal shear-wave velocity and poisson's ratio 933 distribution in Northwest Spain. J. Geodynamics, 25, 1, 35-45.

934

935 Téllez, J., Matias, L.M., Cordoba, D. and Mendes-Victor, L.A., (1993). Structure of the 936 crust in the schistose domain of Galicia-Tra-os-Montes (NW Iberia Peninsula).

937 Tectonophysics, 221, 81-93.

938

939 Torné, M., Pascal, G., Buhl, P., Watts, A.B. And Mauffret, A., (1992). Crustal and

940 velocity structure of the Valencia trough (western Mediterranean), Part I. A combined

941 refraction/wide-angle reflection and near-vertical reflection study. Tectonophysics, 203, $9421-20$.

943

944 Udías, A. (1975). First deep seismic sounding in Spain, Cádiz-Cartagena and Alboran

945 Sea region. Geodynamic Highlights, 2, 30-31.

946

947 Udías, A. (1980). Deep Seismic Sounding Studies in Spain. Final Rep. Comm. on the 948 Geodynamic Project. C.S.I.C., 43-57.

949

950 Vidal, N., Gallart, J. and Dañobeitia, J.J. (1998). A deep crustal seismic transect from the

951 NE Iberian Peninsula to the Western Mediterranean. J. Geophys. Res., 103 (B6), 1238195212396.

953 
954 Watts, A.B., M. Torné, P. Buhl, A. Mauffret, G. Pascal And B. Pinet, (1990). Evidence for

955 reflectors in the lower continental crust before rifting in the Valencia trough. Nature, 348, $956 \quad 631-635$

957 Watts, A.B., Platt, J.P. and Buhl, P., (1993). Tectonic evolution of the Alboran Sea.

958 Basin. Basin Res., 5, 153-177.

959 Wessel, P. and Smith, W.H.F., (1998) New, improved version of the Generic Mapping

960 Tools released. EOS Trans AGU, 79, 47, 579.

961

962 Whitmarsh R.B., Miles P.R. and Mauffret A., (1990). The ocean-continent boundary

963 off the western continental margin of Iberia-I. Crustal structure at $40^{\circ} 30^{\prime} \mathrm{N}$. Geophys.

964 J. Int., 134 509-531.

965

966 Whitmarsh, R. B., White, R. S., Horsefield, S. J., Sibuet, J.-C., Recq, M. and Louvel, V.

967 (1996). The ocean - continent boundary off the western continental margin of Iberia III.

968 Crustal structure west of Galicia Bank. J. Geophys. Res., 101, 28291-28314.

969

970 Working Group For Deep Seismic Sounding In Alboran 1974, (1978). Crustal seismic

971 profiles in the Alboran sea-preliminary results. Pageoph, 116, 166-180.

972

973 Zeyen, H.J., Banda, E., Gallart, J. and Ansorge, J. (1985). A wide-angle seismic

974 reconnaissance of the crust and upper mantle in the Celtiberian chain (Spain). Earth and

975 Planetary Science Letters, 75, 393-402.

976 


\section{$-41-$}

977 Zitellini, N., Rovere, M., Terrinha, P., Chierici, F., Matias, L., and BIGSETS Team,

978 (2004). Neogene through Quaternary tectonic reactivation of SW Iberian passive

979 margin. Pure Appl. Geophys. 161 (3), 565-587.

980

981

$982 \quad$ Figure Captions

983

984 Figure 1: Location of the compiled refraction/wide-angle reflection and deep 985 multichannel reflection profiles beneath the Iberian Peninsula and surrounding waters.

986 Different colours account for each main experiment. Offshore circles depict the position

987 of OBS instruments. Inland circles represent stations having recorded onshore-offshore 988 profiles.

989

990 Figure 2: Velocity-depth distributions along representative transects. The directions 991 have been chosen to follow the zones with available models. (a) NNW-SSE (b) E-W 992 (North Iberia) (c) E-W (Central Iberia). The main tectonic units are indicated on top of 993 each transect. CM: Cantabrian Mountains, Ib M: Iberian Massif, "W Ib Margin”: West 994 Iberian Margin, BCB: Basque Cantabrian Basin, "Val Tr": Valencia Trough, "Ib Ch" 995 Iberian Chain, "Bal Pro": Balearic Promontory. Each transect includes its topographic 996 profile. The inset presents a simplified geological map of Iberia showing the geometry 997 of the transects.

998

999 Figure 3: Compilation of crustal depth thicknesses along published deep seismic 1000 sounding profiles overlying a smoothed topograpic map. 


\section{- 42 -}

1002 Figure 4: Interpolated crustal depth model for the whole investigated area. Colour scale

1003 depicts the crustal thickness variations. Crustal thickness isolines are represented every $10042 \mathrm{~km}$. 


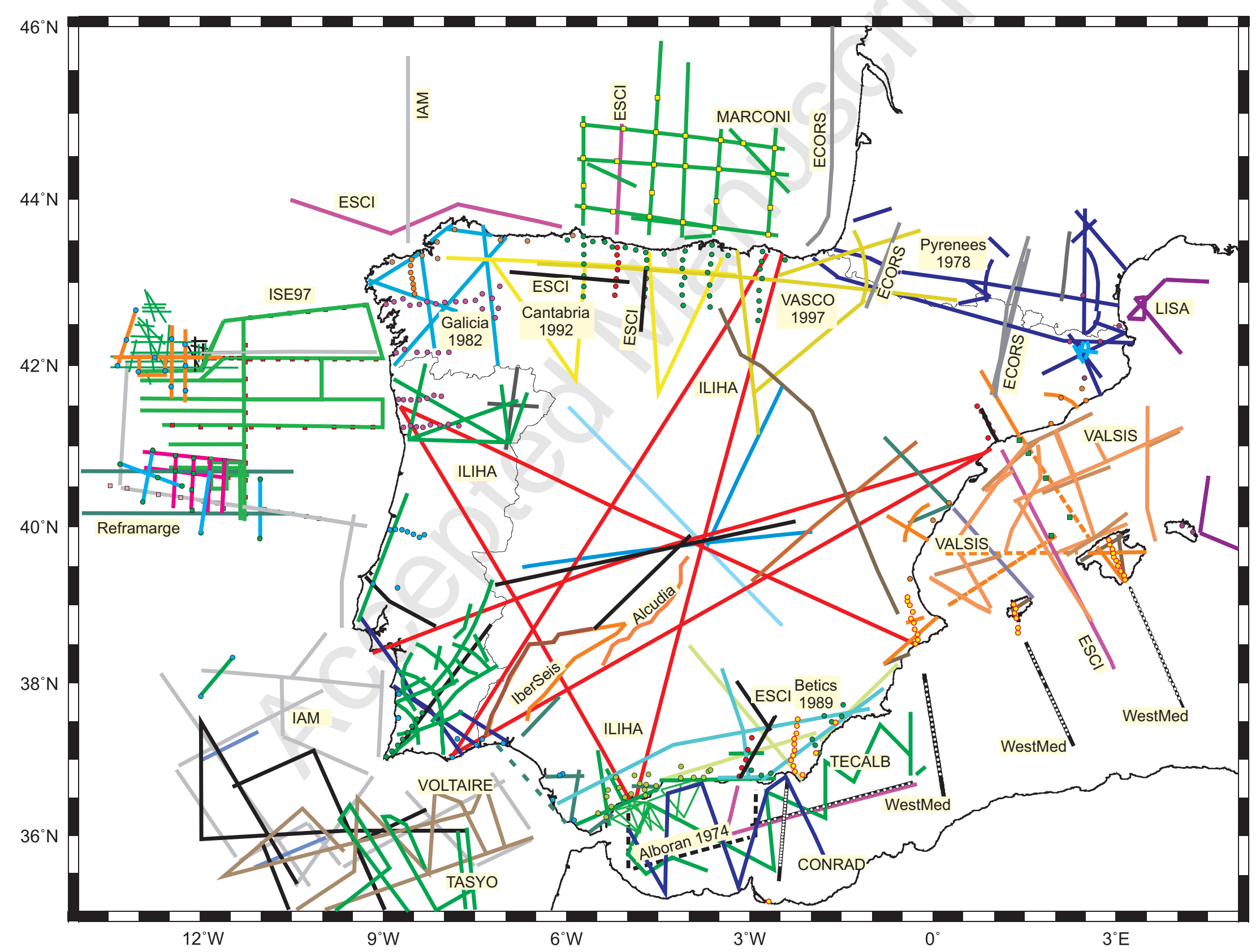

Figure 1 


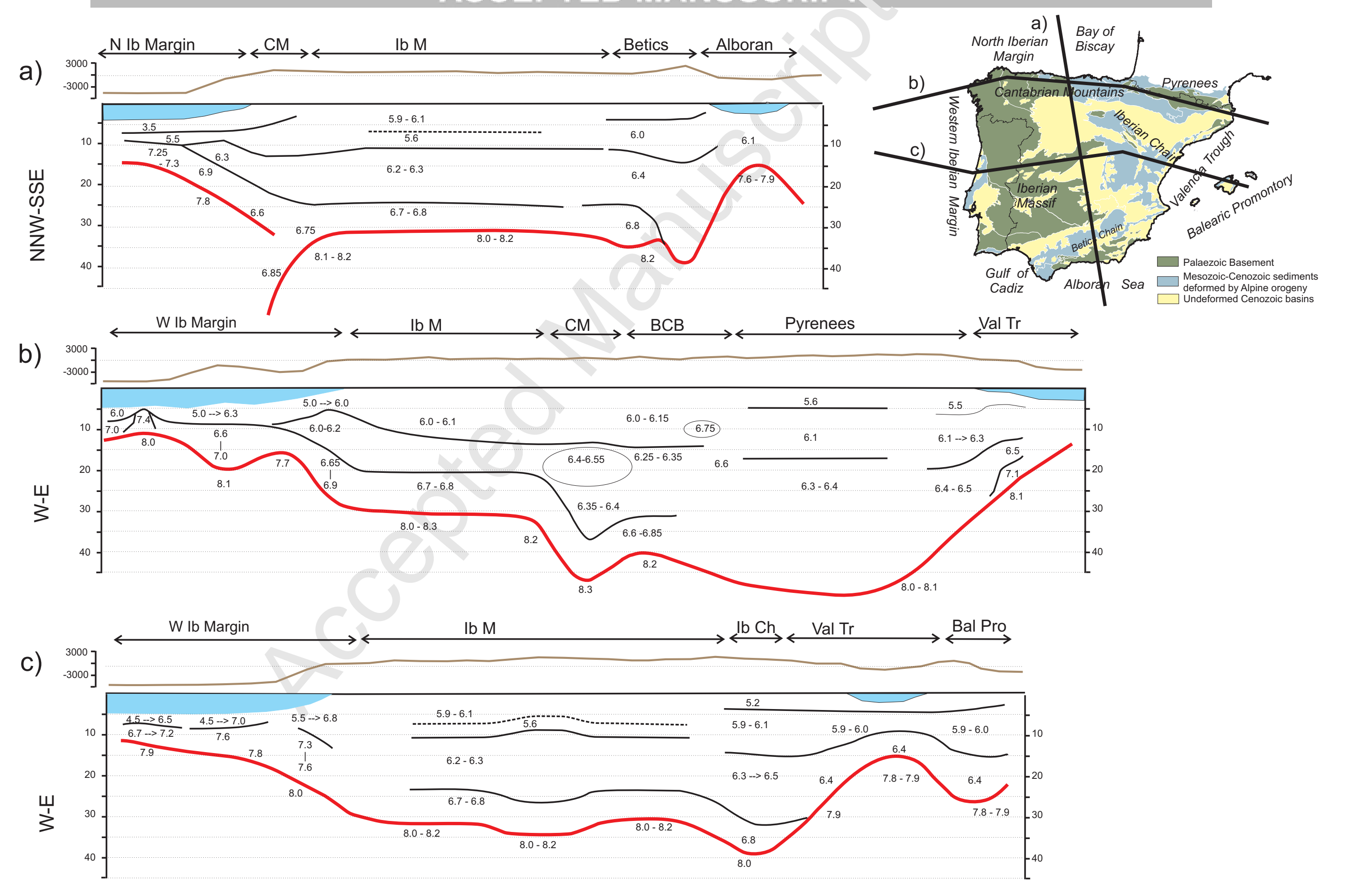

Figure 2 


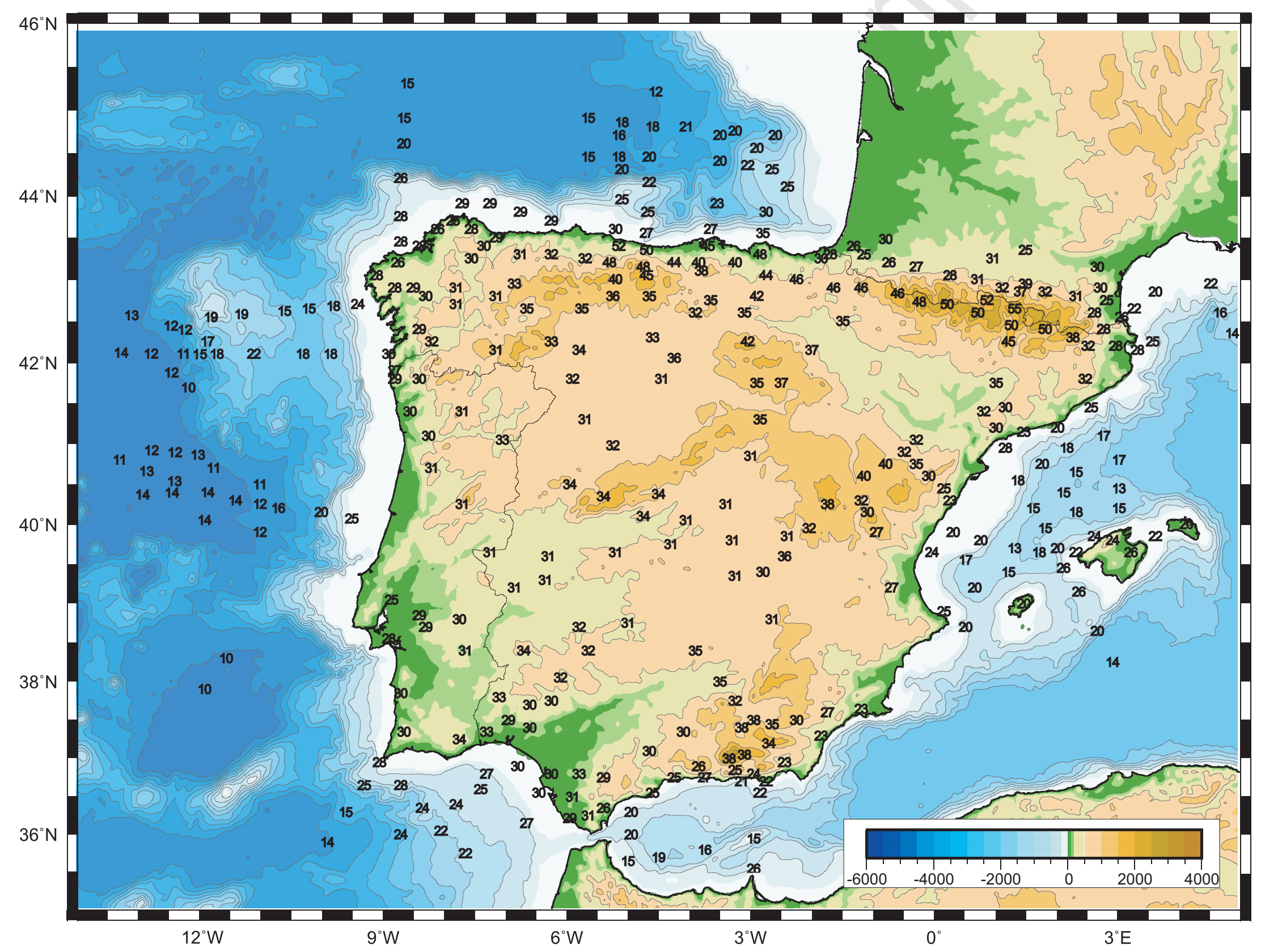

Figure 3 


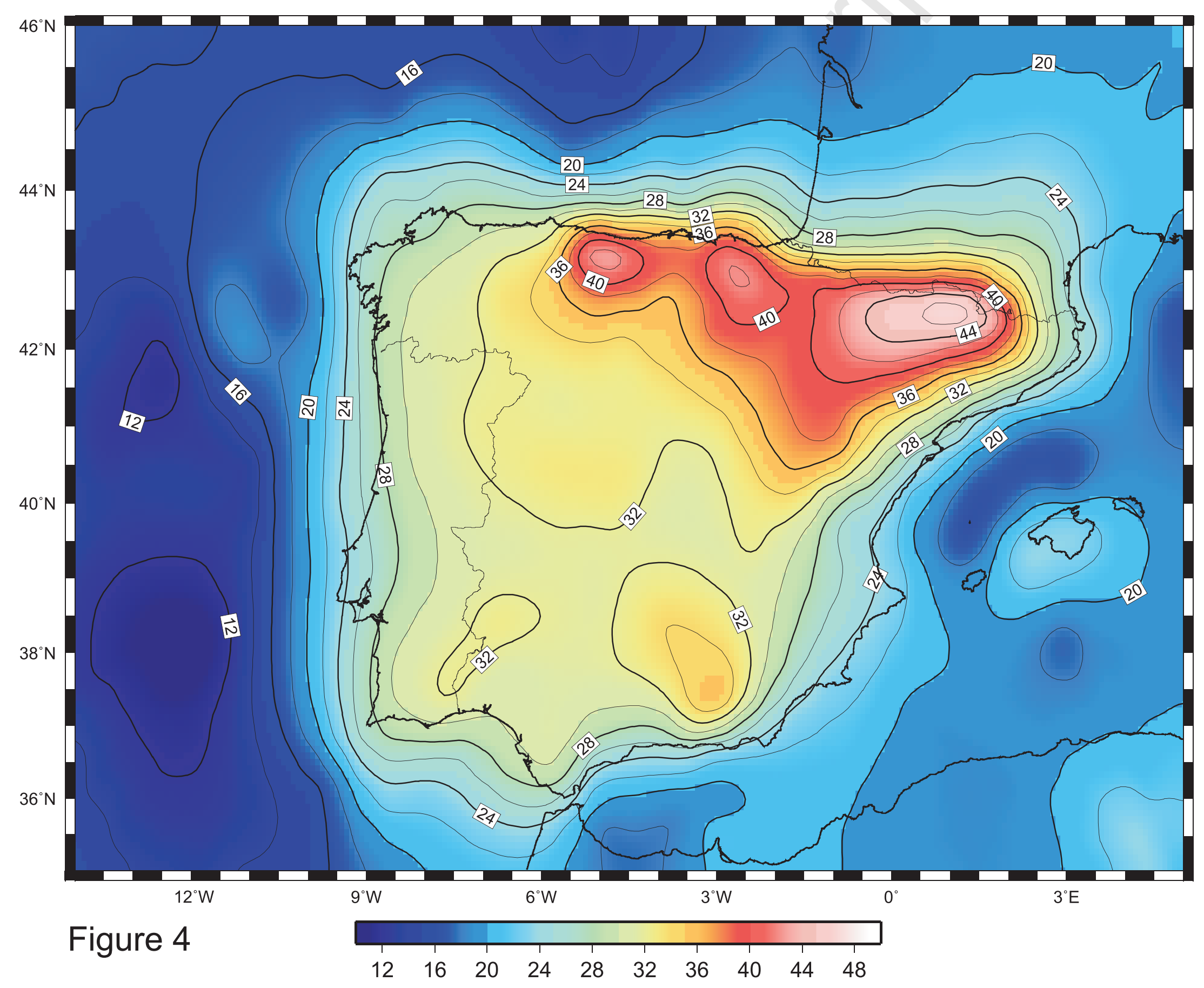

